\title{
Iberian roofing slate as a Global Heritage Stone Province Resource
}

Department of Geology and Soil Science, Ghent University, Krijgslaan 281, Building S8, 9000 Ghent, Belgium. Email: victor.cardenes@ ugent.be

(Received March 23, 2014; Revised accepted September20, 2014)

The Iberian Peninsula is, nowadays, the main producer of roofing slate of the world. Most of the outcrops are located in the NW of the Iberian Peninsula, in the regions of Galicia, Leon, and in Portugal. The technique of working and roofing with slate was brought from Flanders by King Felipe II by the second half of the XVI century. The most representative building from this period is the Monastery of El Escorial, $N$ Madrid. However, the Spanish slate industry remained incipient until the 1960s, when Galicia and Leon suffered an accelerated industrialization process which greatly enhanced the volume of production. Additionally, the Portuguese slate industry was well developed by the second half of the XIX century. Most of the Portuguese production was exported, mainly to the United Kingdom. By the second half of the XX century, the Spanish, and in a lesser extent, the Portuguese roofing slate spread all over Europe, forcing most of the existing European quarries to close. Nowadays, different varieties of roofing slates are quarried, mainly in Spain, being used indistinctly in new residential construction and for restoration of historical buildings. The main importing countries are France, Germany and the United Kingdom. This work presents an overview of the history and main varieties of the Iberian roofing slate, in order to propose its inclusion as a Global Heritage Stone Province.

\section{Introduction}

Roofing slate is the commercial term for a wide variety of rocks that have in common their ability to be split into thin, large and plane tiles. The metamorphic degree of the Iberian roofing slates ranges from the greenschist to the amphibolite facies. Nowadays, the largest roofing slate outcrops over the world are located in the Iberian Peninsula, which produces about $60 \%$ of the slate tiles sold in the world (Fig. 1). However, there are also other countries with important slate outcrops like Brazil and China.

Most of the Spanish slates come from the Ordovician terrains of the Truchas Syncline (Martínez Catalán et al., 1992), a macro structure located between Valdeorras, La Baña and El Bierzo, located in the South-East of Orense and the North-West of Leon, in the NW of Spain. However, there are other important outcrops outside this area which played an important role as slate source areas in the past, creating a local economic motor for the population. Thus, Iberian slate lithotects can be divided into 12 districts, following historical and geographic criteria (Fig. 2). This division is widely used today in the slate sector (Cárdenes et al., 2008).

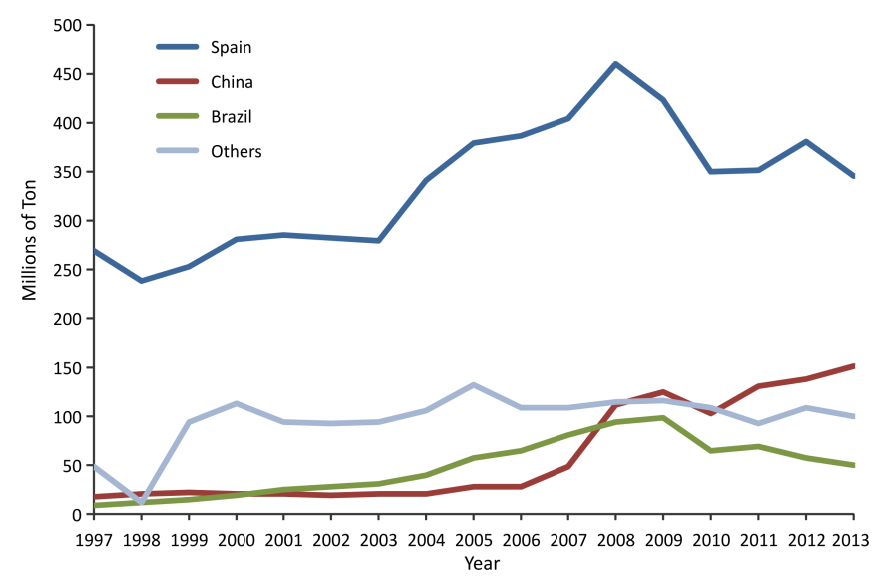

Figure 1. World's exportations of roofing slate for the period 19672013. Data: UNSTATS, United Nations Comtrade

\section{Checklist for Global Heritage Stone Province (GHSP) citation}

\section{Historic use and geography}

The first uses of slate in the Iberian Peninsula can be found during the Chalcolithic period, as material for making arrow heads and similar tools (Fabregas, 2008) at the archeological outcrop of Trabazos de Aliste (Zamora). Later, during the VI-VII centuries, slate is used as a writing base for the so-called "Visigothic numeral slates" (Cordero and Martin, 2012) in the area of Montijo, Badajoz. In both archeological sites, the slates documented come from actual roofing slate districts. Slate was used over the centuries by the inhabitants from settlements close to the outcrops. However, the modern slate industry in the Iberian Peninsula begins during the XIX century.

\section{Portugal}

Historically Portugal had a good relationship with the UK. The 

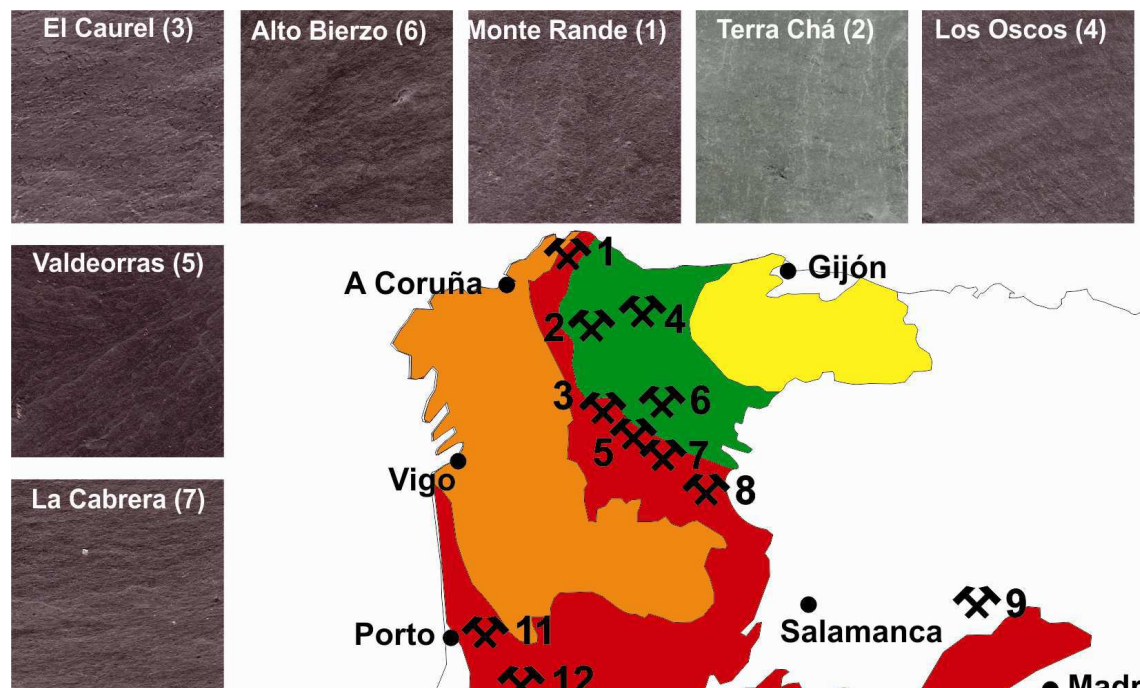

Aliste (8)

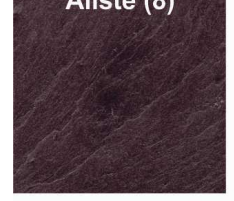

Valongo (11)

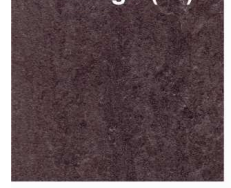

Arouca (12)

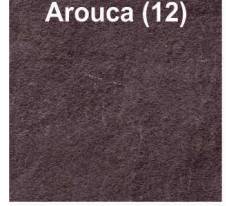

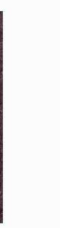

A Coruñ
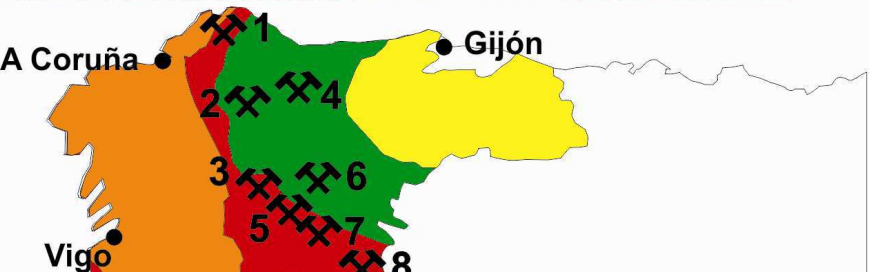

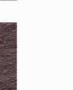

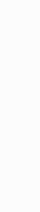

\section{.}

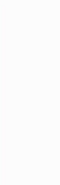

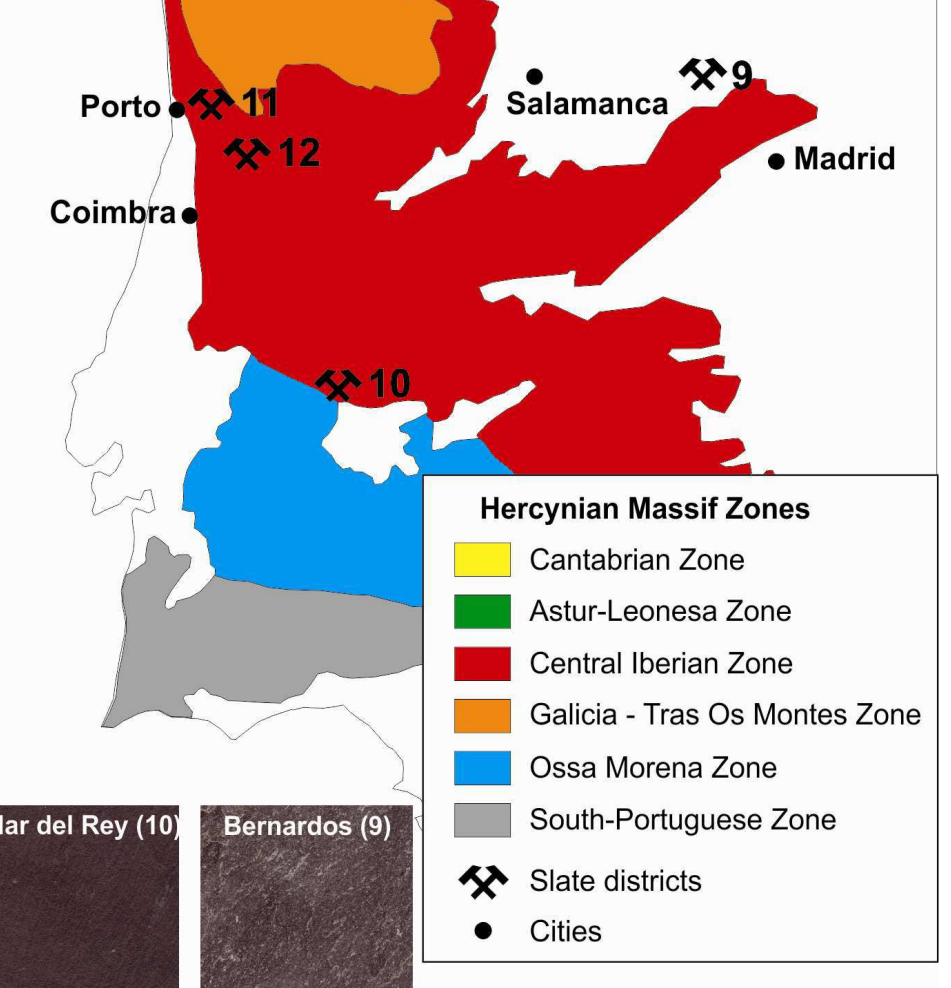
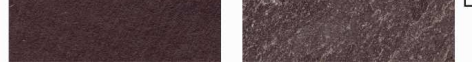

Figure 2. Location of the slate quarries on the Iberian Peninsula and districts classification. development of the slate industry was done on their first stages by Englishmen. The modern slate mining began in 1865, with the foundation in the region of Valongo of the English company The Vallongo Slate \& Marble Quarries (Santos de Oliveira, 1997). The English company owned the mines in Galinheiro, Cardósias, Valle de Amores and Susão.In 1874, these slates were appointed as the main supplier of the Royal House. At the end of the $19^{\text {th }}$ century the company exported over 40 tons of slate todifferent countries such as Brazil, Russia, and Denmark and mostly to Great Britain, and it employedover 500 workers. As new applications (billiard tables, pavements, chimneys, etc.) for the slate were created, the industry increased. In 1930, The Vallongo Slate \& Marble Quarries is absorbed by the new company Empresa das Lousas de Valongo S.A. The new company reached up to 1.600 workers, but in 1939, the beginning of WWII marks a negative point of inflexion for the slate business (Santos de Oliveira, 1997). During the years of the war, the business decreased dramatically, since most of the production was exported to the UK. Neither after the war the exportations recovered, since national governments protected their local industries. Thus, UK consumed construction was quarried at Bernardos (Segovia), located about 75 kilometers North of San Lorenzo de El Escorial. The outcrops were seized by order of the King in order to secure the supply of slates. During the Spanish Baroque period, the use of slate consolidated.

At the same time, the mining industry developed in order to satisfy the demands of the building industry. Bernardos quarries provided most of the slates needed for the construction, since the Valdeorras and Villar del Rey outcrops were still not exploited to their fullest potential. At that time, in the second half of the 16th century, Valdeorras was rather isolated from the rest of Spain. The first mentioning of slate quarrying in Valdeorras is found in the 18th century (García Tato, 1994). The first Valdeorras slate quarries were located along the valley of the Casaio river. These quarries were worked only by locals. There was no machinery, and the mining labors had to be done only using blood power, or the strength of men and animals. This task was especially hard since most of the outcrops were located in mountain areas, with altitudes over $1800 \mathrm{~m}$.

The slate from Valdeorras was only used locally until the beginning of the 20th century, when an English company, Cantabrian Slate 

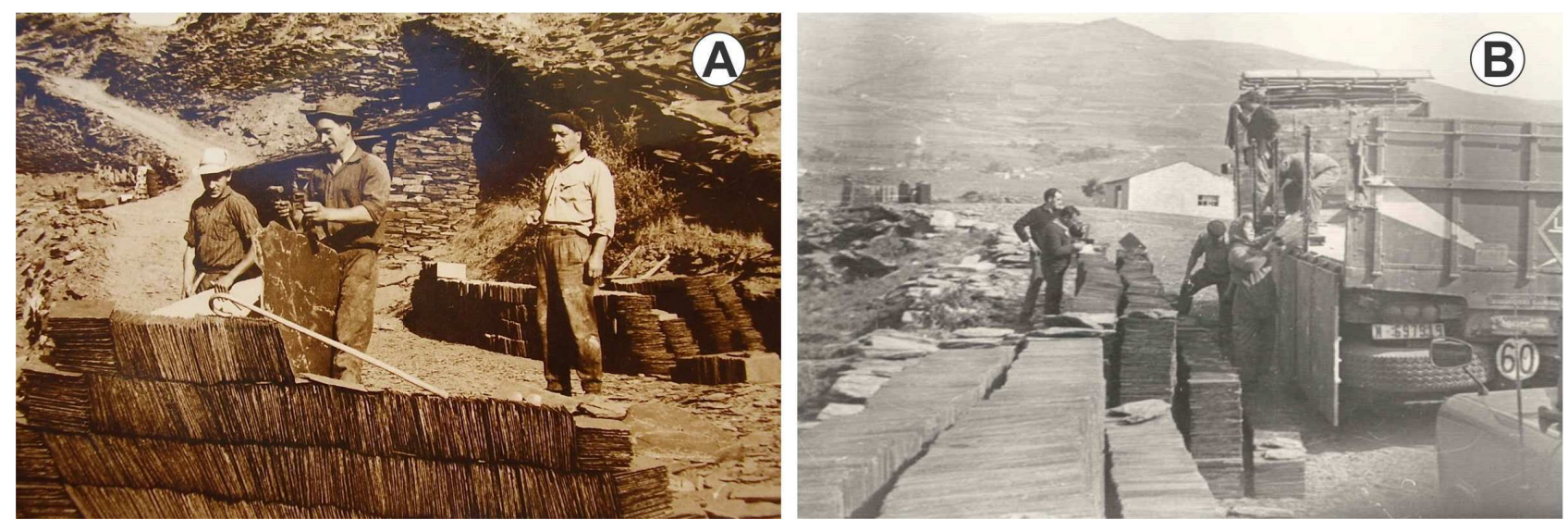

Figure 3. The beginning of the modern slate industry in Valdeorras. (A) Splitting of a slate block just in the middle of the mountai, Valley of Casaio. Photograph courtesy of Manuel Fernandez, Casaio. (B) Load of tiles directly in a truck. Photograph courtesy of Pizarras SAMACA, S.A.. This method caused many tiles to broke before arriving to destiny.

Quarries Ltd, opened a quarry in Congosto, located in El Bierzo, the neighboring region to Valdeorras, also located in the Truchas Syncline. However, the lack of experience made this company to exploit one of the poorest outcrops of Northern Spain and finally they were forced to close in 1931 (The London Gazete, 07/31/1931). It took several years before they tried again to exploit slates from these areas. At thistime French technicians prospected the area and discovered the high resources potential. In the 60's, an accelerated industrialization process took place in these areas. French, and later Germans, used their know-how in the manufacturing of slate tiles, especially in dimensioning the tiles following their own templates. Before that, slates were cut without following any normalized template, so each piece had different dimensions. With the introduction of hand dies that could dimension the tile into regular shapes in seconds, the production increased in quality and quantity. This industrialization process was also favored by the rupture of the agrarian communities due to the emigration (San Román Rodriguez, 2000). However, the new promising slate industry reverted the emigration tendency in some areas (Fig. 3A). Tools used at that time were the same as for agriculture.

In 1962, an engine of a dismantled truck was the first compressor to be working in the Valdeorras slate industry and the first mechanical shovel arrived at the end of that decade. Black gunpowder cardtriges were stuck by hand in order to pull out the big blocks of slate(García Tato, 1994). This process caused a high number of cracks in the blocks, but continued to be used until the early 90's, when the Italian technology of diamond wire saw allowed to increase enormeously the explotation ratio of the slate outcrops. This technology brought also a secondary advantage for geologists and engineers. Because now it became possible to clearly see the relationships between the main structures in the slate, sedimentation $\mathrm{S}_{0}$ versus slaty cleavage $\mathrm{S}_{1}$ and they better understood the regional geology.

Transportation was done by lorries to the port or directly to the warehouses. The slates were stuck inside two types of crates, road crates or ship crates, depending on the method of transportation. Sometimes tiles were directly stuck on the truck (Fig. 3B). Nowadays, only ship crates are used, because they are more solid and appropiate for the sucessive changes of transportation, up to 12 times a crate might suffer before arriving to its destination. In these years, the slate industry in Villar del Rey (Badajoz, Fig 1-10) and Terra Cha (Lugo, Fig 1-2) took its first steps. In Villar del Rey slates had been used for construction for at least 300 years. Due to its proximity with the
Portugal border, some British-Portuguese investors saw the potential of the outcrops and opened the first quarries. On the other hand, the green phyllites from Terra Cha never had been quarried since a slate company with Italian and Spanish founding (IPISA) opened the first quarries during the 60's.

During the 70's, the sector consolidated and the first cooperative societies were formed (Pizarras SAMACA and Cupire Padesa, nowadays named CUPA PIZARRAS). Today, these two companies are still the leading companies of the world slate production. The Spanish slate irrupted in the European market, especially in France helped by the strikes of the French slate workers of the late 70's.

In the 80 's, first pneumatic cuters were introduced and the legislation of the dumps began. Before that they were dumped without governmental criteria, only using the quarrymen criteria. In the 90 's, the sector was shaken by numerous strikes that lasted for several months, making the situation very hard for both workers and owners. During the second half of this decade and the first half of the 21st century, the exportations increased continuosly year after year. This period was the most profitful for the slate industry. Finally, in 2008 the global crisis began to hit hard in the sector, leading many companies to close and putting the rest in a very difficult situation. Nowadays, several slate districts have closed their quarries (Villar del Rey, Terra Cha, Aliste, El Caurel, La Cabrera) and many others are threatened by the current economicalcrisis.

Compared to Portugal, the Spanish slate industry was developed much later, and with a considerably lower degree of industrialization. However, the Spanish outcrops are much bigger than the Portuguese, so nowadays Spain is leading the slate sector, but with some challenges needed to face urgently, like the competition with the emerging countries such as Brazil and China, and the neccesary restructuring of the sector, that still suffers from some handicaps inherited from the past.

\section{Formal Name for this proposed GHSP}

Iberian slate province

\section{Origin of name}

Roofing slates from the Iberian Peninsula

\section{Other names}

None 


\section{Area of occurrence}

Spanish Provinces of A Coruña, Lugo, Ourense and Leon, in NW Spain, Segovia, center of Spain, and Badajoz, SW Spain. Portuguese provinces of Arouca and Valong, N Portugal.

\section{List of constituent GHSP designations that are included within this} designated Province

As pointed before, there are 12 slate districts in the Iberian Peninsula (Fig. 2):

1. Monte Rande slate, Ortigueira, in A Coruña. Dark-grey slate. Two active quarries at this moment.

2. Terra Cha phyllite, Pol, in Lugo. Light-green phyllite with abundant pyrite cubes. No active quarry at this moment.

3. El Caurel, Quiroga, in Ourense. Light-grey slate with characteristic crystals of chloritoid. Not working at this moment.

4. Los Oscos, Fonsagrada, in Lugo. Light-grey slate. One active quarry.

5. Valdeorras, in Ourense. This district is the largest one, of all, with more than 50 quarries. Slates from Valdeorras range from dark to light grey colors. Several varieties can be recognized (IGME, 1991):
a. Casaio
b. Castañeiro
c. Mormeau
d. Rozadais
e. Los Molinos
f. Domiz
g. Vianzola
h. PenedoRayado
i. San Vicente
j. Forna

6. Alto Bierzo, Laciana, in Leon. Light-grey slates, no quarry working at this time.

7. La Cabrera, in Leon. This is the second district in order of importance, with about 20 quarries working. These slates are mainly greyish. As for Valdeorras, there are several varieties:
a. San Pedro de Trones
b. Benuza
c. La Baña
d. Odollo

8. Aliste, Bercianos de Aliste, in Leon. Dark-grey slate, no quarry working at this time.

9. Bernardos, in Segovia, N Madrid. Light grey phyllites. There are two quarries, owned by the same company, that are still working.

10. Villar del Rey, in Badajoz. Dark slate with abundant iron sulphides and organic matter, no quarry working at this time.

11. Valongo, Portugal. Light grey slate, two active mines.

12. Arouca, Portugal. Dark slate, one active quarry.

\section{List of other known constituent heritage stone types}

No other significative heritage stones are quarried in this proposed GHSP.

\section{Geological setting}

The proposed GHSP is located at the Hercynian terrains of the Iberian Peninsula (Fig. 2). Most of the slate outcrops can be found on Ordovician terrains (Table 1, Fig. 4).
Table 1. Geological settings of the slate districts from the Iberian Peninsula

\begin{tabular}{|c|c|c|}
\hline & Slate districts & Formations / Geological structure / Age \\
\hline 1 & Monte Rande & $\begin{array}{l}\text { Luarca slates / W of the Ollo de Sapo } \\
\text { Anticlinorium / Upper Ordovician }\end{array}$ \\
\hline 2 & Terra Cha & $\begin{array}{l}\text { Cándana slates / Mondoñedo Thrust / } \\
\text { Lower Cambrian }\end{array}$ \\
\hline 3 & Caurel & $\begin{array}{l}\text { Luarca slates / Truchas Syncline / } \\
\text { Middle Ordovician }\end{array}$ \\
\hline 4 & Los Oscos & $\begin{array}{l}\text { Luarca slates / Mondoñedo Thrust and } \\
\text { Narcea Anticlinorium / Middle Ordovician }\end{array}$ \\
\hline 5 & Valdeorras & $\begin{array}{l}\text { Luarca slates, Casaio, Rozadais and Losadilla } \\
\text { formations / Truchas Syncline / Ordovician }\end{array}$ \\
\hline 6 & Alto Bierzo & Luarca slates / Truchas Syncline / Ordovician \\
\hline 7 & $\begin{array}{l}\text { La Cabrera - } \\
\text { La Baña }\end{array}$ & $\begin{array}{l}\text { Luarca slates, Casaio, Rozadais and Losadilla } \\
\text { formations / Truchas Syncline / Ordovician }\end{array}$ \\
\hline 8 & Riofrio & Luarca slates / Alcañices Syncline \\
\hline 9 & Bernardos & $\begin{array}{l}\text { Santa MariaBeds / Santa María la Real Massif / } \\
\text { Precambrian }\end{array}$ \\
\hline 10 & Villar del Rey & $\begin{array}{l}\text { GevoraUnit / San Mamed - La Codosera } \\
\text { Synclinorium / Devonian }\end{array}$ \\
\hline 11 & Valongo & $\begin{array}{l}\text { Valongo slates / Valongo Syncline / Middle } \\
\text { Ordovician }\end{array}$ \\
\hline 12 & Arouca & $\begin{array}{l}\text { Valongo slates / Valongo Syncline / Middle } \\
\text { Ordovician }\end{array}$ \\
\hline
\end{tabular}

From a stratigraphic point of view, the productive formations are as follows (Cárdenes et al., 2013):

- Santa María Beds, from the Santa María la Real Massif (Álvarez, 1982), belonging in turn to the Schists Greywacke Complex. Quarries are located to the North of Madrid, in the province of Segovia. The slates are slightly sandy, greenishgrey colored, with numerous sandstone and quartzite levels, more abundant to the top and bottom of the stratigraphic section. These are the roofing slates of the Iberian Peninsula which present the highest metamorphic grade, reaching the biotite isograde.

- Formation Cándana Green Slates (Compte, 1959), from the Group Middle Cándana. These are green slates and schists with abundant carbonates and centimetric cubic crystals of pyrite. The characteristic mineral for these slates is clinochlore, which gives them the green color. Outcrops are located in the province of Lugo, N Spain, in MondoñedoThrust Domain. These slates have a low fissility grade, being used mostly for flooring.

- Luarca Slates Formation (Barrois, 1882) is the largest roofing slate lithotect in the Iberian Peninsula. Main outcrops are found in the Truchas Synclinorium (Fig. 5)and El Caurel Domain (Marcos, 1973), covering the provinces of Lugo, Orense and León. It consists of a monotonous sequence of black slates with thin sandy levels. To the bottom and top of the stratigraphic section there are volcano-sedimentary levels, and to the middle part there is an iron nodule level, which in some localities have been quarried. The slate is black, fine grained, with abundant iron sulfides to the top. In the slates from El Caurel Domain is usual to find chloritoid well developed, visible with naked eye. In N Portugal, the equivalent lithotect is the Valongo Slates Formation (Romano and Diggens, 1974). 


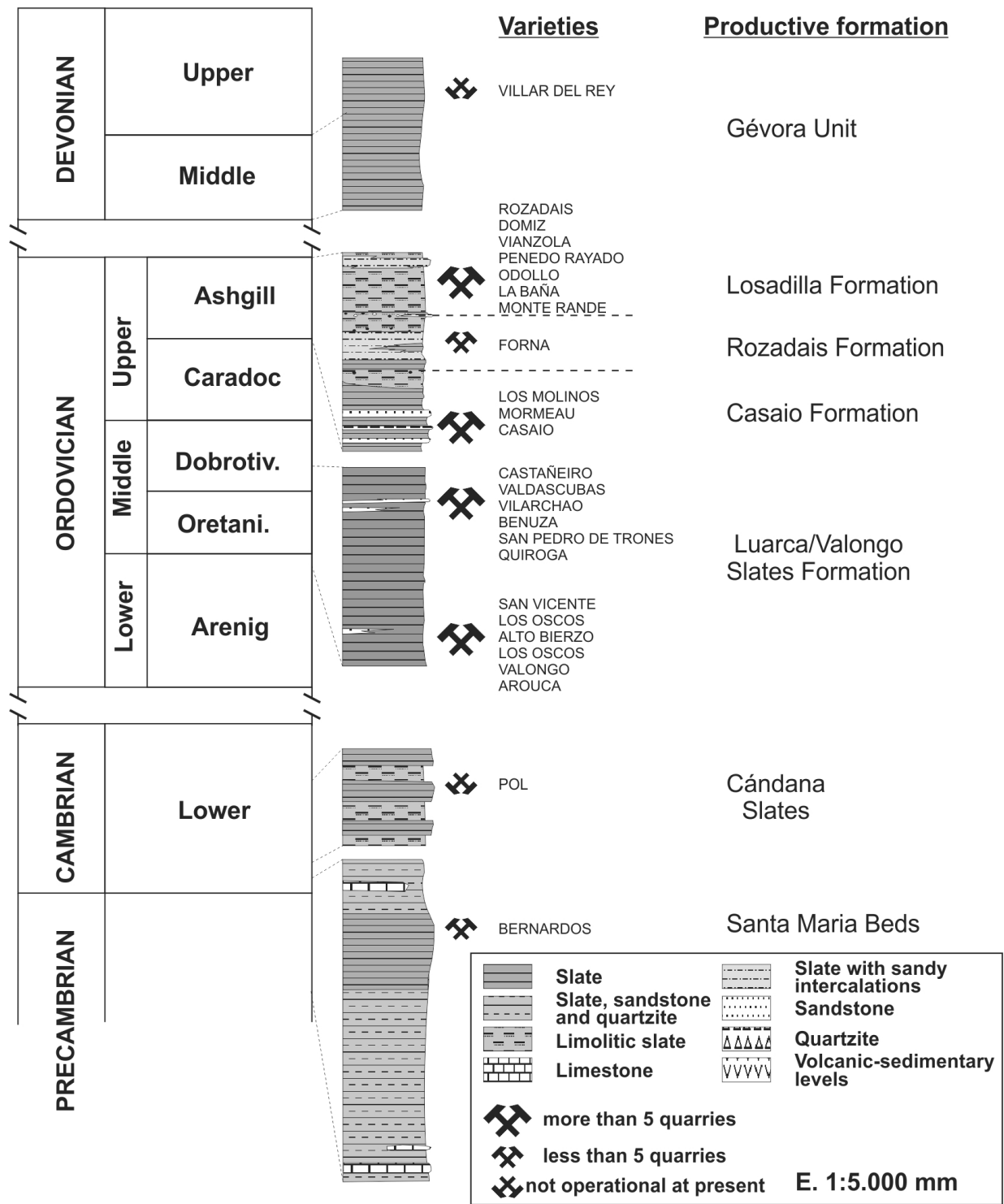

Figure 4. Stratigraphic column for the Iberian Peninsula slate varieties.

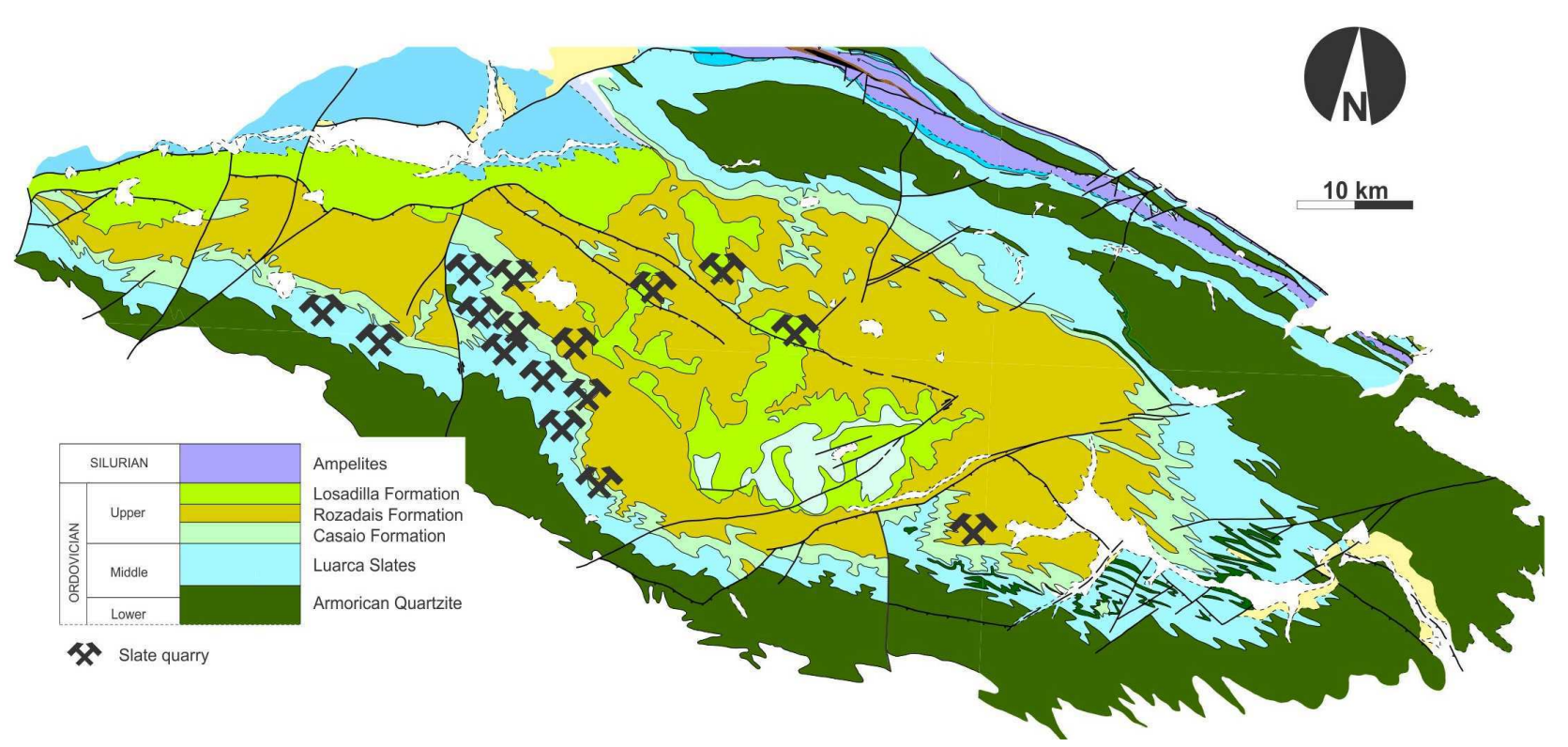

Figure 5. Geological map of the Truchas Syncline, with the main slate outcrops represented. Modified from Heredia et al., unpublished. 


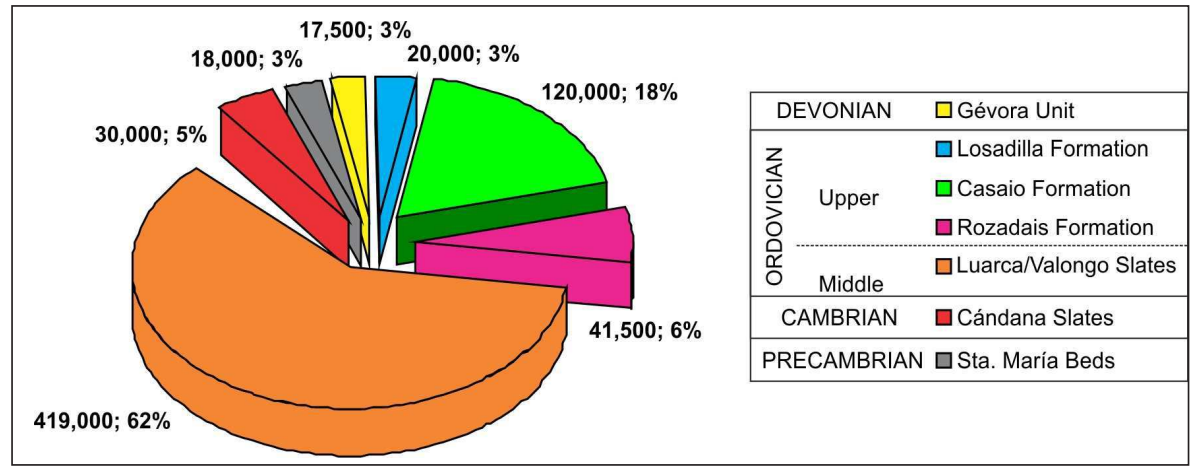

Figure 6. Slate production by Formations. Data from UNSTATS, United Nations Comtrade, 2009.

- Casaio, Rozadais and Losadilla formations (Barros, 1989) for the Truchas Syncline Domain, and Agüeira Formation (Marcos, 1973), outside the Syncline. Casaio Formation consists of light grey slate, with coarse detritic lithologies and iron sulfides. Most of the quarries are placed in this formation. Rozadais Formation has predominance of slaty terms, with some quartzite intercalations, and fragments of limestone and sandstone to the top. These pelite fragments (pelítes à fragments) can be recognized in other localities of the European Hercynian chain. Finally, Losadilla Formation, the less productive, is represented by light grey slates with sandy laminations, with high quartz content.

- Gévora Unit (Santos-García and Casas, 1979), in the southern area of the Central Iberian Zone, in the province of Badajoz. The outcrops are located in the La Codosera-Puebla de Obando Synclinorium. These slates are black, medium grained, homogeneous, with abundant inclusions of cubic pyrite and organic matter.

The main, by far, productive formation is the Luarca Slates, from Middle Ordovician (Barrois, 1882), mainly quarried at the Truchas Syncline (Catalan et al., 1992). Other Ordovician formations (Casaio, Rozadais and Losadilla) are quarried at the Truchas Syncline, with a considerable volume of production (Fig. 6).

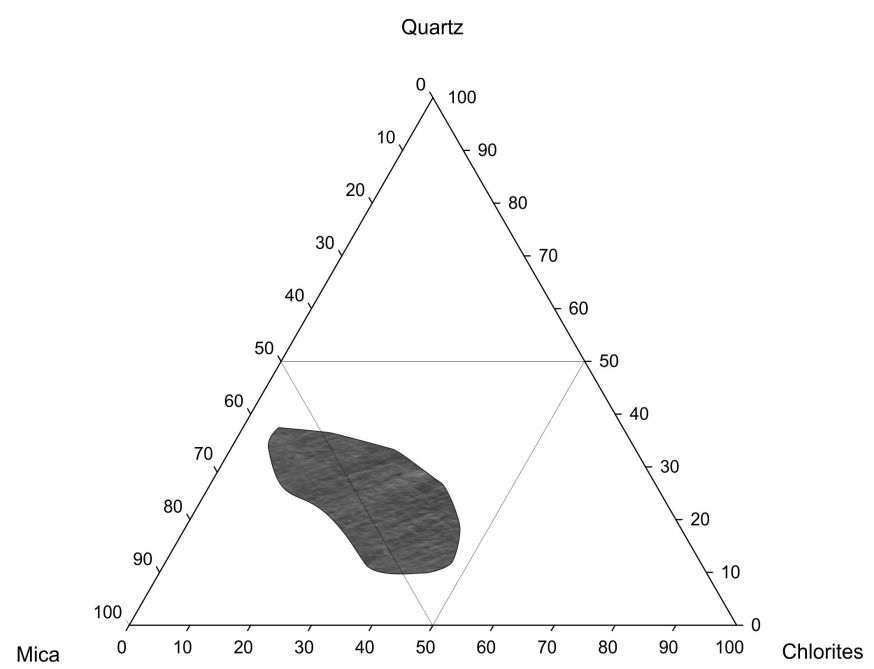

Figure 7. Triangular diagram for the three main mineral components. The shadowed area represents the average values for Iberian roofing slates.

\section{Unifying characteristics of this province}

The proposed GHSP comprises the roofing slates from the Iberian Peninsula. By definition, roofing slates are a fine grained group of stones which have the ability to be split into thin, plane and large tiles. In the Iberian Peninsula two types of rocks agree with these conditions, slates s.s. and phyllites (Arkai et al., 2007). Technical characteristics of these rocks are very similar. As a general condition, they fulfill the requirements of the European Norm for roofing slates EN 12326 (AEN/ CTN_22, 2011). The main characteristics that together form a good slate tile are mineralogy and geochemistry (weatherability) and petrographic texture (fissility).

Iberian roofing slates are very uniform in mineralogy, with three main minerals (quartz, mica and chlorites, Fig. 7) and some accessories like chloritoid, iron sulphides, carbonates, organic matter, rutile and tourmaline.

Regarding to the geochemistry, the elemental composition of the Iberian slates is rather homogeneous (Fig. 8). The average values and standard deviation (in brackets) for the major elements are $\mathrm{SiO}_{2}$ : 56.03(3.35), $\mathrm{Al}_{2} \mathrm{O}_{3}: 22.09$ (1.97), $\mathrm{Fe}_{2} \mathrm{O}_{3}: 8.06$ (1.33), $\mathrm{MnO}: 0.09$ (0.03), $\mathrm{MgO}: 2.37$ (0.52), $\mathrm{CaO}: 0.44$ (0.23), $\mathrm{Na}_{2} \mathrm{O}: 1.29$ (0.73), $\mathrm{K}_{2} \mathrm{O}$ : 4.05 (0.73), $\mathrm{TiO}_{2}: 1.15(0.22), \mathrm{P}_{2} \mathrm{O}_{5}: 0.16(0.16)$.

From a petrographic point of view, the texture of the slates is very characteristic, lepidoblastic or porfiro-lepidoblastic (Fig. 9). This texture always shows a penetrative slaty cleavage, with clear alignments of the clasts. There is a special requirement of the EN 12326 for roofing slates regarding to petrography, that is the calculation of the Mica Stacking Index (MSI). This index calculates the density and thickness of the mica levels that form the slaty cleavage planes, and it is related with the fissility(Cárdenes et al., 2010).

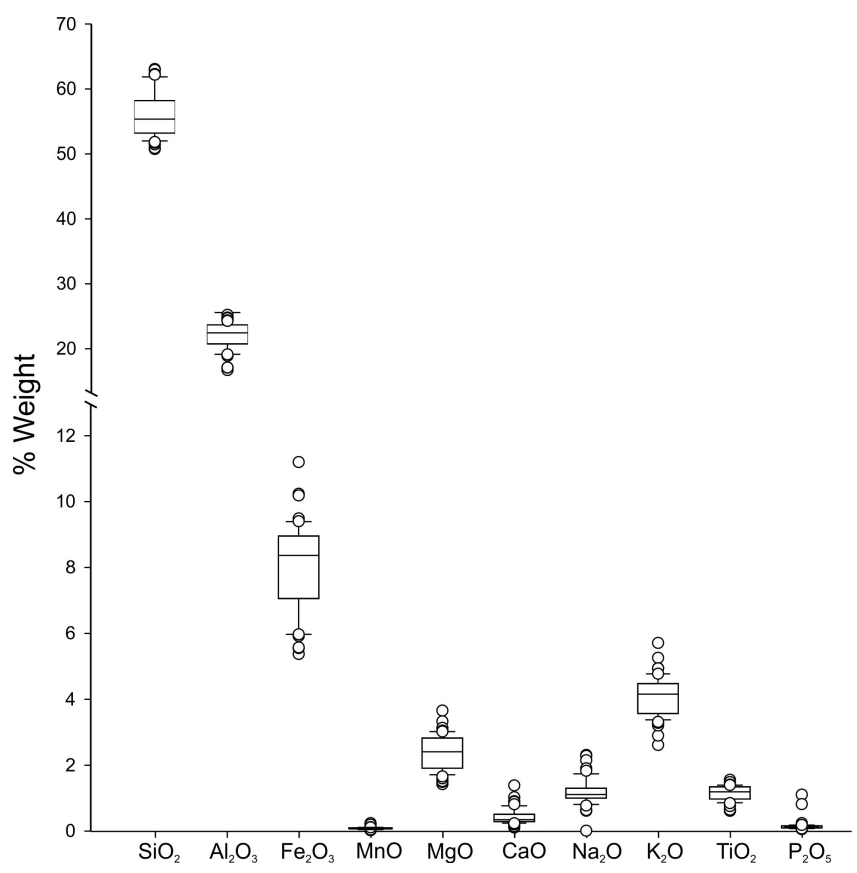

Figure 8. Major elements composition for Iberian roofing slates. 

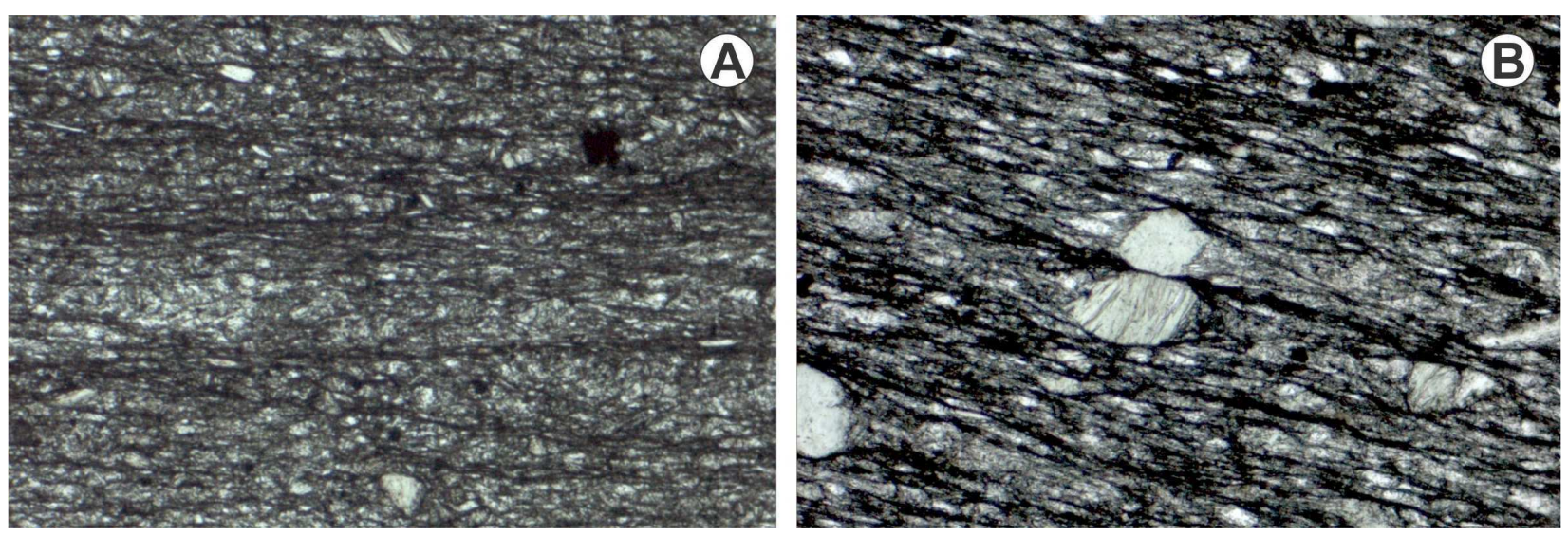

Figure 9. The two characteristic microscopic textures for Iberian roofing slates. (A) Lepidoblastic texture, Luarca Slates Formation, Valdeorras. (B) Porphyro-lepidoblastic texture, Rozadais Formation, Valdeorras. Both microphotographs taken with parallel nichols, 200x magnification.

\section{Natural variation of geology within this province}

The geology of the different areas that form the proposed province falls within the Hercynian of the Iberian Peninsula. However, all these areas have some important geological features in common. All of them are located in the Hercynian terrains of the Iberian Peninsula, showing none or very slight deformation; otherwise it would be impossible to obtain regular tiles. The metamorphic range is rather short, from 200 to $400{ }^{\circ} \mathrm{C}$ of temperature and 20 to $40 \mathrm{MPa}$ of pressure. The original sediments were in all cases pelites (Cárdenes et al., 2013).

\section{Vulnerability}

There are enough reservoirs in all the districts, with the exception of the district of Bernardos. This district has been quarried from more than 500 years, and now it is close to its exhaustion. However, there is always the possibility to continue the works by opening a mine, like in other countries (France, Germany) that have been quarrying slate for hundreds of years. This option has been taken into account by several companies in Bernardos but also in other districts, such as Valdeorras and La Baña. In case there would be needed substituting slate from a heritage building with a different source slate, a protocol of acting has been developed (Cárdenes et al., 2014; Prieto et al., 2011), taking into account the mineralogy and aesthetics of the slate.

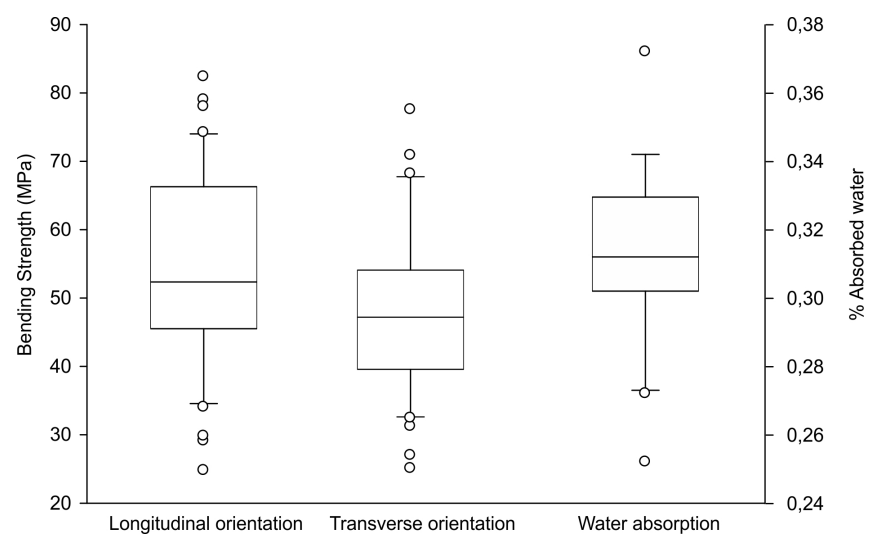

Figure 10. Average values for bending strength (right) for both longitudinal and transverse orientations. On the left, average values for water absorption. Data from the Technological Center of Slate, Sobradelo de Valdeorras, Spain.

\section{Construction}

Nowadays, about $80 \%$ of recent buildings in Europe with slate covershave Iberian slate. Also, many buildings from the European heritage have been restored with Iberian slate, or still keep the original slate, as in the case for El Escorial Palace in Spain.

Technical and aesthetic characteristics for Iberian roofing slates are very similar. The tests needed for commercializing, according to EN 12326, are bending strength (calculated in both longitudinal and transverse orientations respect of the tile), water absorption (Fig. 10), freeze-thaw resistance, oxidizability by thermal cycling and petrographic characterization. This set of tests is focused on the requirements of a roofing material. From a durability point of view, roofing slates can be affected by two main pathologies, oxidation and gypsification. The oxidation is the result of the weathering of the iron sulphides (mainly pyrite and pyrrhotite) that the slate may content, while gypsification is the transformation of the carbonates to gypsum. The relative abundances of the potentially harmful minerals are between 0 and $4 \%$ for iron

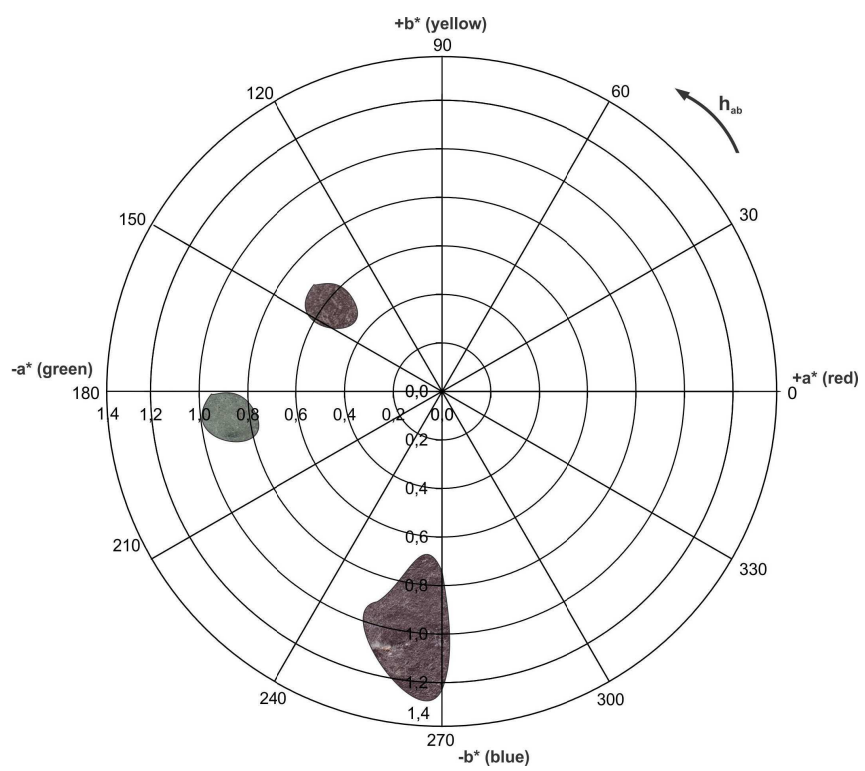

Figure 11.CIELAB color space: representation of the area in which the chromatic parameters: $a^{*}, b^{*}, C * a b$ and hab of the slates studied are included. Shaded area corresponds to the average coordinates for Spanish roofing slates. 

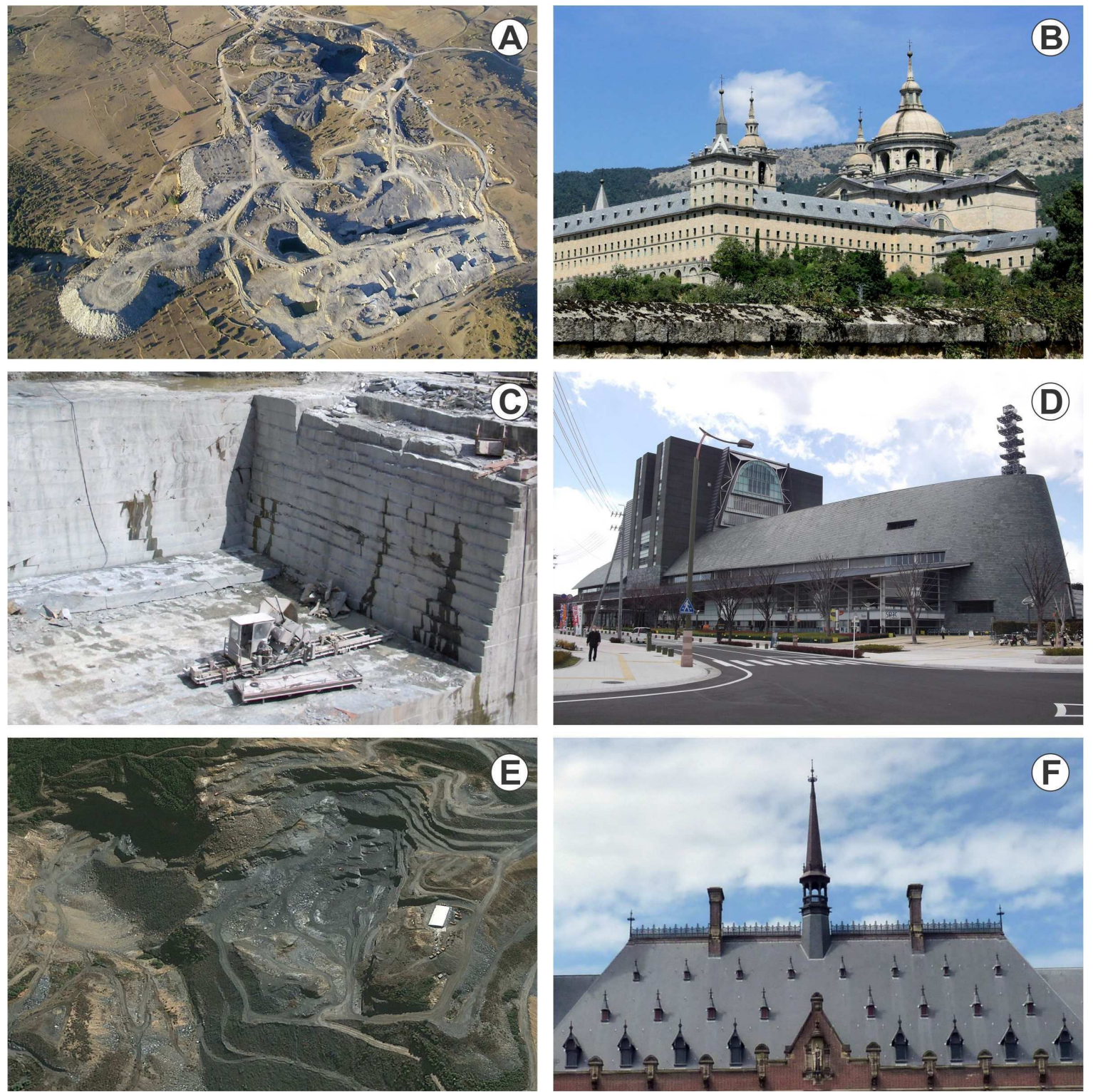

Figure 12. Some of the most important representative Iberian slate quarries, together with emblematic buildings made with their slate: A. Quarry from Bernardos, Segovia, Spain.Image: Pizarras J. Bernardos. B. Royal Monastery of San Lorenzo de El Escorial (1563-1584), Spain, one of the most important buildings in Spanish Heritage constructed by and for King Felipe II, originally covered with slate from Bernardos. C. Quarry for the variety Verde Pol, in Lugo, Spain. D. Shizouka Convention and Arts Center (1999), Shizouka, Japan, made with Verde Pol Photo: IPISA. E. Quarry from Los Molinos, Ourense, Spain. Image: Google maps. F. Peace Palace (1907 - 1913), The Hague, The Netherlands, place for the International Court of Justice, slate from Los Molinos quarry.Image: CUPA Pizarras.

sulphides and between 0 and $2 \%$ for carbonates.

Regarding to aesthetics, slates have colors ranging from black dark to light grey, with the exception of the phyllites from Lugo, that are light green (Fig. 11).

Some examples of representative buildings (Fig. 12) made with Iberian roofing slate are:

- The Peace Palace (1907-1913), The Hague, The Netherlands.

- Merlemont Castle (17 $7^{\text {th }}$ century), Val d'Hermeton, Philippeville, Belgium.

- Baelen Castle (17 $7^{\text {th }}$ century), Welkenraedt, Belgium.

- Mitsubishi Ichigokan Museum of Arts (1864), Tokyo, Japan.

- Church Notre Dame, Laeken, Brussels, Belgium (1854).

- Kerfily Castle (1858-1863), Elven, Morbihan, France.

- Pontevedra Auditorium, Spain.
- Shizouka Convention and Arts Center (1999), Japan.

- Royal Monastery of San Lorenzo de El Escorial (1584), Madrid, Spain.

- Royal Mint House (1580), Segovia, Spain.

- Palace of Cardenal Espinosa (1572), Segovia.

- Santa Cruz Palace (1629-1643), Madrid, Spain.

- Parish church of Santa Bárbara (former Royal Monastery of La Visitación, 1757), Madrid, Spain.

\section{Conclusions}

The Iberian Peninsula is, nowadays, the main producer of roofing slates of the world. As pointed before, about $80 \%$ of the world's production comes from the Iberian Peninsula. Roofing slates from 
the Iberian Peninsula are rather homogeneous both from constructive and petrological points of view, with only some differences among them in color and mechanical performance. They are present in many of the European building heritage and also in actual buildings. These facts give sense to the proposal of a Global Heritage Stone Province for the Iberian roofing slate.

\section{Acknowledgements}

Victor Cárdenes is grateful to the Foundation for the Scientific Research (FWO) from the Flanders Government, Belgium, for his Pegasus Marie Curie Fellowship.

\section{References}

AEN/CTN_22, 2011. EN 12326. Slate and stone products for discontinuous roofing and cladding - Parts 1 (Product Specification) and 2 (Methods of test).

Álvarez, F., 1982, Contribución al estudio tectónico de la región de Santa Maria la Real de Nieva (Provincia de Segovia). Temas Geológicos Mineros, v. 6, no. pp. 87-108.

Arkai, P., Sassi, F.P. and Desmons, J., 2007. Very low to low-grade metamorphic rocks. In: D. Fettes and J. Desmons (Editors), Metamorphic Rocks. A Classification and Glossary terms. Cambridge University Press, pp. 6 .

Barrois, C., 1882, Recherches sur les terrains anciens des Asturies et de la Galice. Mémoires de la Société Géologique du Nord de la France, v. 2, no. 1 .

Barros, J.C., 1989, Nuevos datos geológicos y cartográficos sobre el flanco Sur del Sinclinorio de Truchas. Cadernos do Laboratorio Xeolóxico de Laxe, v. 14, no. pp. 93-116.

Cárdenes, V., de la Horra, R., Monterroso, C., García-Guinea, J. and Pais, V., 2008. Depósitos de pizarras para cubiertas en la Península Ibérica, VII Congreso Geológico de España. Sociedad Geológica de España, Las Palmas de Gran Canaria, pp. 453.

Cárdenes, V., Rubio-Ordoñez, A., López-Munguira, A., de la Horra, R., Monterroso, C., Paradelo, R. and Calleja, L., 2010, Mineralogy and modulus of rupture of roofing slate: Applications in the prospection and quarrying of slate deposits. Engineering Geology, v. 114, pp. 191-197.

Cárdenes, V., Rubio-Ordoñez, A., Monterroso, C. and Calleja, L., 2013, Geology and Geochemistry of Iberian roofing slates. Chemie der Erde, v. 73, no. pp. 373-382.

Cárdenes, V., Rubio-Ordoñez, A., Monterroso, C. and Mateos, F., 2014, Guidelines for selecting roofing slate for the restoration of historical buildings and monuments: Two case studies. Journal of Cultural Heritage, v. 15 , no. 2 , pp. $203-208$.

Mártinez-Catalán, J.R., Hacar, M., Villar, P., Pérez-Estaún, A. and Gonzalez, F., 1992, Lower Paleozoic extensional tectonics in the limit between the West Asturian-Leones and Central Iberian Zones of the Variscan foldbelt in NW Spain. Geologische Rundschau,v. 81, no. 2, pp. 545-560.

Compte, P., 1959, Recherches sur les terrains anciens de la Cordillère Cantabrique. Memorias del Instituto Geológico y Minero de España, v. 60, pp. 1-440.

Cordero, T. and Martin, I., 2012, Use and chronology of numeral slates: Some remarks on the case of the archaeological site of Valdelobos (Montijo, Badajoz). Archivo Español de Arqueologia, v. 85, pp. 253-266.

Fabregas, R., 2008, The management of quartz and slate resources in the Iberian Chalcolithic: The case of the "Santuario" at El Pedrodo (Trabazos de Aliste, Zamora). Trabajos de Prehistoria, v. 65, no. 1, pp. 125-142.

García Tato, I., 1994. A Explotación Louxeira no Concello de Carballeda. Cuadernos Monográficos, 16. Instituto de Estudios Valdeorreses.

Gutiérrez-Marco, J.C., Sá, A.A., García-Bellido, D.C., Rábano, I. and Valério, M., 2009, Giant trilobites and trilobite clusters from the Ordovician of Portugal. Geology,v. 37, no. 5, pp. 443-446.
IGME, 1991. Pizarras de España.

Marcos, A., 1973, Las series del Paleozoico inferior y la estructura herciniana del occidente de Asturias (NW de España). Trabajos de Geología, v. 6, no. pp. 1-113.

Nieto, V., Morales, A.J. and Checa, F., 2001. Arquitectura del Renacimiento en España, 1488 - 1599. Manuales de Arte Cátedra. Anaya.

Prieto, B., Ferrer, P., Sanmartín, P., Cárdenes, V. and Silva, B., 2011, Color characterization of roofing slates from the Iberian Peninsula for restoration purposes. Journal of Cultural Heritage, v. 12, no. pp. 420-430.

Romano, M. and Diggens, J.N., 1974, The stratigraphy and structure of Ordovician and associated rocks around Valongo, North Portugal. Comunicaçoes dos Serviços Geológicos de Portugal, v. 57, no. pp. 23-50.

San Román Rodriguez, J.M., 2000. Valdeorras. La Industria de la Pizarra y las Transformaciones espaciales. Municipios de O Barco, Carballeda y Rubiá (1950 - 1998). Cuaderno Monográfico, 32. Instituto de Estudios Valdeorreses.

Santos-García, J.A. and Casas, J., 1979, Geología del Sinclinorio de Sao Mamede - La Codosera zona española (Cáceres y Badajoz). Boletín Geológico y Minero, v. XC-V, no. pp. 420-431.

Santos de Oliveira, M.I., 1997, A Mineração no Concelho de Valongo: O Ouro e a Lousa. Museu Municipal Dias de Oliveira. Camara de Valongo, Valongo, $14 \mathrm{pp}$.

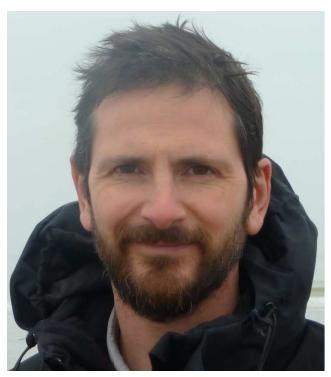

Victor Cárdenes geologist and has a $\mathrm{PhD}$ from the University of Oviedo (Spain) where he focused on several aspects of roofing slates, from petrology to restoration. Presently he is working at Ghent University (Belgium) in the framework of an FWO-Pegasus Marie Curie Fellowship continuing researching in slates.

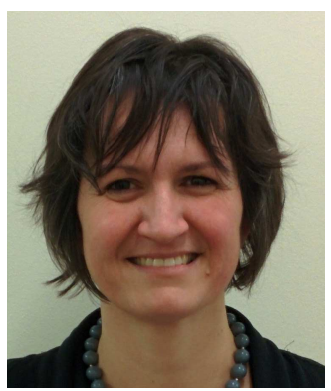

Veerle Cnudde professor at the Department of Geology and Soil Science of Ghent University, and one of the leaders of the Centre for X-ray Tomography (www.ugct.ugent.be). She is also the head of the Pore-scale PROcesses in Geomaterials Research group (PProGRess; www.pprogress. ugent.be). PProGRess holds a strong expertise in the field of natural building stones and the assessment of their properties with specialization in 3D realtime imaging of processes in the pore space of geomaterials.

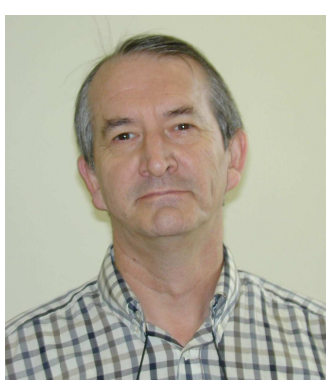

Jean Pierre Cnudde, professor at the Department of Geology and Soil Science of Ghent University studied slaty material since 1968. Being the head of the Belgian delegation since 1986, European Chairman since 2005 of the EN board for the EN 12326 norm for roofing slates. He is an expert for the Certification of roofing slates in Belgium since 1981. 